\title{
THE EFFECTS OF DUST EXTRACTION ON MULTI-CYCLONE AND NON-WOVEN FABRIC PANEL FILTER PERFORMANCE INTHE AIR FILTERS USED IN SPECIAL VEHICLES
}

\author{
WPŁYW ODSYSANIA PYŁU NA CHARAKTERYSTYKI MULTICYKLONU \\ I WŁÓKNINOWEJ PRZEGRODY FILTRACYJNEJ FILTRU POWIETRZA \\ POJAZDU SPECJALNEGO*
}

\begin{abstract}
Common impurities found in the inlet air to the internal combustion engine of motor vehicles are characterized. Dust concentrations in the air were analysed for different operating conditions of a motor vehicle. It is shown that the most common and the most harmful air impurity for the technical machinery is a mineral dust from roads. The benefits of using the inertial filter (multicyclone) as a first stage of air filtration, including extended engine life are presented. The methods of dust extraction from a dust collector of the air filter multi-cyclone are shown. The necessity of regular ejection dust extraction from the multi-cyclone dust collector is shown. A dust extraction rate $m_{0}$ is defined and its effects on the cyclone separation efficiency and flow resistance are shown. The test method and the test conditions for a two-stage filter in multi-cyclone-non-woven fabric filter element configuration are developed. The characteristics of the separation efficiency and flow resistance of the cyclone and the non-woven fabric filter were determined as a function of dust mass supplied with the inlet air to the two-stage filter for three different extraction rates and without dust extraction from the multi-cyclone dust collector. The separation efficiency and flow resistance were determined for a multi-cyclone and a non-woven fabric filter without dust extraction from the multi-cyclone dust collector and with or without periodical maintenance. The benefits of periodical cleaning of the dust collector were shown.
\end{abstract}

Keywords: engines, performance, air cleanness, non-woven fabric filter, separation efficiency, separation performance, surface wear, filter life.

\begin{abstract}
Scharakteryzowano zanieczyszczenia powietrza wlotowego silnika spalinowego pojazdu mechanicznego. Przeanalizowano wartości stężenia pylu w powietrzu dla różnych warunków eksploatacji pojazdów. Przedstawiono korzyści w postaci wydlużenia czasu eksploatacji silnika wynikające ze stosowania filtru bezwładnościowego (multicyklonu), jako pierwszego stopnia filtracji powietrza. Pokazano metody usuwania pylu z osadnika multicyklonu filtru powietrza. Wykazano konieczność bieżacego, poprzez ejekcyjne odsysanie, usuwania pyłu z osadnika multicyklonu. Zdefiniowano stopnień odsysania pylu m0 oraz wykazano jego wplyw na skuteczność filtracji i opory przepływu cyklonów. Opracowano metodykę i warunki badań filtru dwustopniowego pracującego w układzie: multicyklon-włókninowy wkład filtracyjny. Wyznaczono charakterystyki skuteczności filtracji i oporów przepływu multicyklonu oraz włókniny filtracyjnej w zależności od masy pyłu dostarczonej wraz z powietrzem wlotowym do filtru dwustopniowego dla trzech wartości stopnia odsysania $m_{0}=5 \%, m_{0}=10 \%, m_{0}=20 \%$ oraz bez odsysania pylu z osadnika multicyklonu. Wyznaczono charakterystyki skuteczności filtracji i oporów przepływu multicyklonu oraz włókniny filtracyjnej bez odsysania pylu z osadnika multicyklonu i z okresowym obstugiwaniem oraz bez obstugiwania. Wykazano konieczność okresowego czyszczenia osadnika pytu.
\end{abstract}

Stowa kluczowe: silniki, eksploatacja, czystość powietrza, włóknina filtracyjna, skuteczność i dokładność filtracji, zużycie powierzchni, trwałość filtru.

\section{Foreword}

Providing a dust-free inlet air to the internal combustion engines of motor vehicles and machines, and thus reducing wear and improving component life, always was and still is a major operational and design issue, in particular for vehicles operating in heavy-duty terrain and high dust concentration conditions (about $1 \mathrm{~g} / \mathrm{m}^{3}$ ) $[2,10,12,18$, $20,30]$. It generally applies to special vehicles, including military vehicles with high-power diesel engines with a maximum air demand $Q_{\text {Sil }}$ over $1 \mathrm{~kg} / \mathrm{s}$, e.g.: $Q_{S i l}=1.21 \mathrm{~kg} / \mathrm{s},\left(3,400 \mathrm{~m}^{3} / \mathrm{h}\right)$ for T-72 tank engine and $Q_{S i l}=2.15 \mathrm{~kg} / \mathrm{s}\left(6,000 \mathrm{~m}^{3} / \mathrm{h}\right)$ for Leopard 2 tank engine. At dust concentration level $s=1 \mathrm{~g} / \mathrm{m}^{3}$, specific to the vehicles used on testing grounds, the engines of those tanks draw in a stream of dust at $0.94 \mathrm{~g} / \mathrm{s}$ and $1.67 \mathrm{~g} / \mathrm{s}$, respectively.

Two-stage air filters in a multi-cyclone - porous panel filter configuration (usually made of paper filter element or non-woven fabric filter element) are used to remove the dust mass, with particle size $<100 \mu \mathrm{m}[2,4,10]$, from the inlet air stream. The concept of using two-stage filters consists in initial separation of large dust particles in an inertial filter (multi-cyclone) and leaving small dust particles $\left(d_{z}<15 \div 30 \mu \mathrm{m}\right)$ in the air stream and separating small air particles (above $d_{z}=2 \div 5 \mu \mathrm{m}$ ) in the panel air filter - Fig. 1 .

The time in which the air filtration system reaches permissible air filter flow resistance $\Delta p_{\text {fdop }}(5 \div 8 \mathrm{kPa})$ is significantly longer compared

(*) Tekst artykułu w polskiej wersji językowej dostępny w elektronicznym wydaniu kwartalnika na stronie www.ein.org.pl 

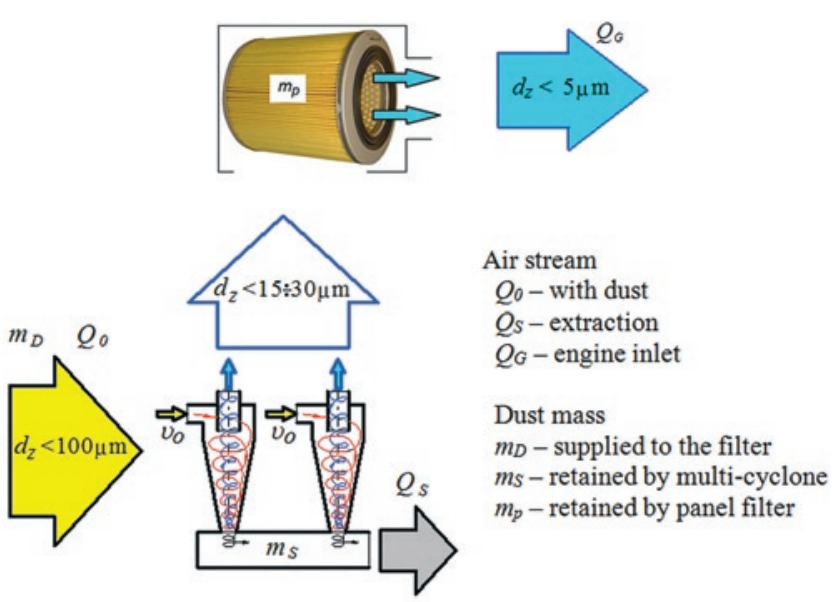

Fig. 1. Air filtration process in the two-stage filter in a 'multi-cyclone-porous panel filter' configuration.

to the panel filter under the same dustiness conditions (Fig. 2). Single filter element with an average separation efficiency of $\varphi_{w}=99.95 \%$ reached a flow resistance of $\Delta p_{w}=9.4 \mathrm{kPa}$ after drawing in $m_{D}=56 \mathrm{~g}$ of dust with air. Similar filter element in a 'cyclone - filter element' configuration reached a similar flow resistance of $\Delta p_{w}=9.65 \mathrm{kPa}$ after drawing in $m_{D}=254 \mathrm{~g}$ of dust with air, i.e. five times more.

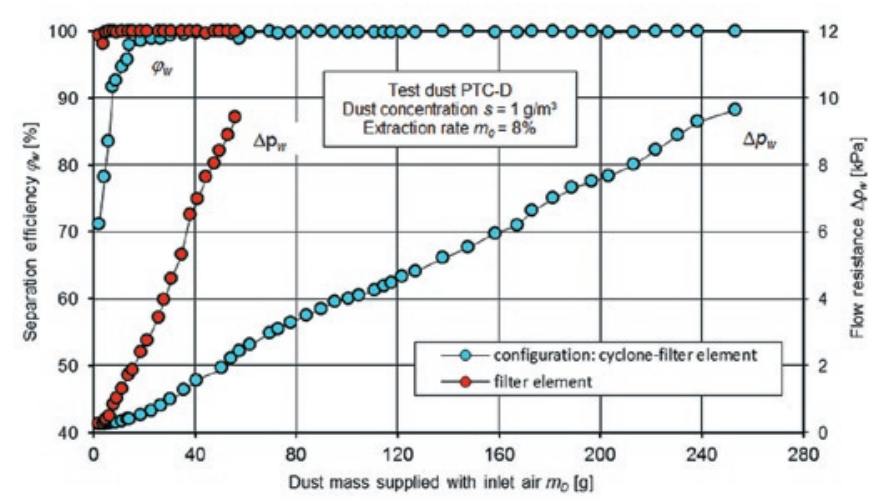

Fig. 2. Change in flow resistance $\Delta p_{w}=f\left(m_{D}\right)$ and separation efficiency $\varphi_{w}=f\left(m_{D}\right)$ of paper filter element in a single configuration and in a cyclone - filter element configuration as a function of dust mass $m_{D}$ supplied with inlet air [12]

A multi-cyclone is a unit including up to several hundred cyclones arranged side-by-side in parallel on the common tube plates (top and bottom). Internal diameter of the cyclones used in the inlet air filters of motor vehicles does not exceed $D=40 \mathrm{~mm}$. As opposed to the industrial cyclones, featuring internal diameters of $D=250 \div 3.000$ $\mathrm{mm}$ ), the cyclones used in air filters are often referred to as minicyclones.

The cyclones used in motor vehicles reach up to $96 \%$ separation efficiency $[2,4,14]$. During the 8 -hour operation of T-72 tank engine in testing ground conditions, the air filter multi-cyclone may retain over $25 \mathrm{~kg}$ of dust. The separated dust is collected in a dust collector common for all the cyclones. The dust mass collected in the dust collector depends on the air stream, dust concentration in air and cyclone efficiency.

Storing a large volume of dust in the dust collector is not recommended due to:

- need to use high capacity dust collector, increasing overall filter dimensions and making the installation difficult,
- secondary dust aspiration due to vehicle vibrations and sudden changes in air stream direction due to changes in engine speed,

- filling up the dust collector and as a result capturing dust and reducing multi-cyclone efficiency,

- unnecessary filter structure load due to the additional weight.

In the multi-cyclones of the air filters of vehicles, in particular vehicles used in high-dust conditions, systematic (continuous) dust extraction from the dust collector using an air stream - extraction stream (ejection effect) is used.

In a multi-cyclone including a large number $(50 \div 100$ and more $)$ of cyclones and a common dust collector, usually one or two ports are used for the dust extraction from the dust collector.The distances between the outlet ports of the streams extracted from each cyclone from the extraction system port may differ, creating problems with the dust extraction from the extreme individual cyclones. It further reduces the cyclone efficiency, and thus reduces the separation efficiency and performance of the entire multi-cyclone. The dust mass supplied to the second filtration stage is larger and further reduces the filter life (vehicle mileage) until the permissible flow resistance is reached.

The cyclone performance is usually validated by numerical tests using CFD (Computational Fluid Dynamics) software [1, 3, 7, 8, 15, $17,21,22,26,28,32]$. CFD software provides a detailed analysis of any issues related with the fluid flows, and eliminates time-consuming and expensive experiments in the design and retrofitting stage. The software provides relevant flow data (velocity field distribution, pressure field), heat transfer (temperature field) and mass transfer by numerical solving of the equations describing the changes in momentum, energy and mass balance.

There are scarce studies concerned with numerical [29] and experimental $[4,10,11,19]$ evaluation of the performance of dust extraction systems used in the multi-cyclone dust collectors.

Thus, assuming that the experimental tests are the most reliable research method, an experimental evaluation of the performance and the effects of the dust extraction from the dust collector of the motor vehicle air filter on the filtration process in the porous panel filter is presented in the study.

\section{Impurities in inlet air of internal combustion en- gines}

Atmospheric air drawn in by the internal combustion engines of motor vehicles contains large quantities of impurities, which can be classified as gaseous impurities (organic and inorganic) and particulate impurities $[2,4,5,6]$. Dust is a dispersed phase of a two-phase system including particulate matter suspended in a gaseous dispersion phase, i.e. mixture of solid particles suspended in air.

The sources of dust emission are both natural phenomena and human activity. The dust emissions from natural sources are prevalent on a global scale. The most common natural dust emission sources are: volcanoes, deposits, marine aerosols, animal and plant materials, and forest fires [5].

In high-intensity industrial areas, the major dust emission sources are anthropogenic sources, including all production and fuel combustion processes, mostly solid fuels. Large dust volumes are generated by the power industry, chemical industry, mining industry, metallurgical industry and construction industry, in particular cement production [6].

The particulate matter can be classified by particle dimensions [5]:

- total particulate matter - mixture of small solid particles (suspended in air); conventional dimension $<300 \mu \mathrm{m}$,

- suspended particulate matter PM10 - conventional dimensions $<10 \mu \mathrm{m}$, 
- fine particulate matter PM2.5 - conventional dimensions $<2.5 \mu \mathrm{m}$,

- nano particulate matter PM1 - conventional dimensions $<1 \mu \mathrm{m}$.

All particulate matter $<1 \mu \mathrm{m}$ may cause premature wear of machine components and must be removed from the engine inlet air by the air filters.

The particulate matter (PM10 and PM2.5) emission from anthropogenic sources is mainly related to a road transport due to the largescale character of motor vehicle use. It contributes to approx. $15 \%$ of both size fractions of the particulate matter $[5,27]$. The particulate matter from motor transport (road transport) have the following sources $[2,5,9]$ :

- mineral dust (road dust, with silicon dioxide as a main component) lifted from the road surface due to the movement of motor vehicles or wind,

- exhaust gases from motor vehicle engines (dust, carbon black, lead compounds, heavy hydrocarbons, particulate matter and gases),

- particulate matter from sliding pairs of motor vehicles, i.e. wear of friction linings of brakes and clutch plates [4],

- dust from tyre and surface wear due to interaction of wheels and road surface [4].

The most common impurity present in air, which is also harmful to any technical equipment is a road dust, lifted from the surface due to the traffic or wind, and supplied with inlet air to the motor cylinders.

The road dust is a polydisperse dust characterized by diversified physical and chemical properties, with basic components including grains of hard minerals: silicone dioxide (silica) and aluminium trioxide (corundum), which contribute to $60 \div 95 \%$ of dust content [2]. The hardness of silica particles, determined in a ten-degree Mohs scale is 7 , whereas for corundum it is 9 , i.e. more than for structural materials used for the construction of internal combustion engines. The dust particles are solids with irregular shape and sharp edges.

One of the characteristic properties of air is the dust concentration, measured as a dust mass (in grams or milligrams) in $1 \mathrm{~m}^{3}$ of atmospheric air. Dust concentration in air is a variable and depends on many factors. Dust concentration in air may vary depending on the operating conditions of a motor vehicle.

The lowest dust concentration in air, approx. $0.001 \mathrm{~g} / \mathrm{m}^{3}[2,4,11]$ can be observed on hard surfaces and roads, and $<0.001 \mathrm{~g} / \mathrm{m}^{3}$ in residential areas. The highest dust concentration up to $3,8 \div 7 \mathrm{~g} / \mathrm{m}^{3}[2,9,13,18,20]$, can be observed for a convoy of tracked vehicles on the testing ground with dry surfaces. Dust concentration in air at the air intake during helicopter takeoff and landing may reach up to $3 \mathrm{~g} / \mathrm{m}^{3}$. Dust concentration in air may reach $10 \mathrm{~g} / \mathrm{m}^{3}$ during a sandstorm [20]. It is over 1000 times higher compared to the dust concentration on the city roads with motor vehicle traffic. a)

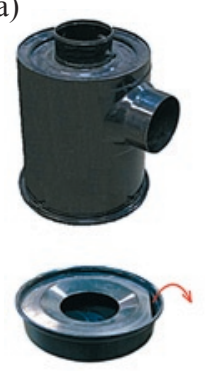

The dust suspended in air also reduces visibility (Fig. 3) and thus affects road safety. Dust concentration in air of $0.7 \mathrm{~g} / \mathrm{m}^{3}$ significantly reduces the visibility and at $1.5 \mathrm{~g} / \mathrm{m}^{3}$ the visibility is practically reduced to zero [10].

Part of the impurities supplied to the engine cylinders via the air supply system is combusted, and some are removed with the exhaust gases. Only $10 \div 20 \%$ of dust introduced to the engine via its inlet system is deposited on the cylinder sleeve walls. This dust forms an abrasive paste with oil, which in contact with a sliding pair pistonpiston rings-cylinder (P-PR-C) results in a premature wear of cylinder sleeve, piston rings and ring grooves. The clearance between the (PPR-C) increases, resulting in the reduction of the combustion chamber leak-tightness.

It results in a decrease in compression pressure and engine power [16], an increase in blow-by to the crankcase [24], further increasing the engine oil degradation. The engine performance and start-up capabilities of a cold engine are also affected. Fuel and engine oil consumption, as well as the emission of toxic compounds are also increased [25].

As a result of piston movement in the direction of the bottom dead centre, the piston rings remove the oil with any impurities from the cylinder bearing surface to the oil sump. The impurities are distributed in the lubrication system via the oil system to the friction areas which require oil lubrication, i.e. the following pairs: crankshaft neckbushing, camshaft neck-bushing, valve guide-valve stem, resulting in premature wear.

The friction wear takes place where any hard solids are trapped between two mating surfaces, deform and cut micro-volumes of the surface layer of mating elements at different depths.

The authors studying the effects of impurities present in the operational fluids on the wear of piston engine components claim, that the most extensive wear is due to the dust particles with dimensions $d_{z}$ corresponding to the minimum thickness $h_{\min }$ of oil film required to form an oil wedge between the mating surfaces [16].

\section{Methods of dust removal from dust collector of air filter multi-cyclone}

Removing the dust from a dust collector of an air filter multicyclone in legacy solutions was carried out by the driver as part of

c)

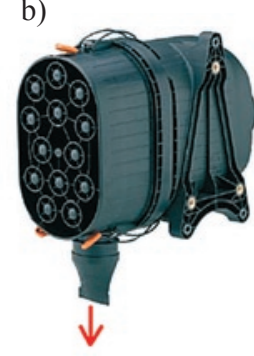

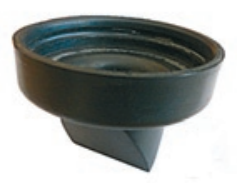

Fig. 4. Dust extraction methods for inertia filters: a) manual (Jelcz 317 filter), b) rubber drain cone (Mann+Hummel filter), c) rubber drain cone d) ejection (T-72 tank filter)
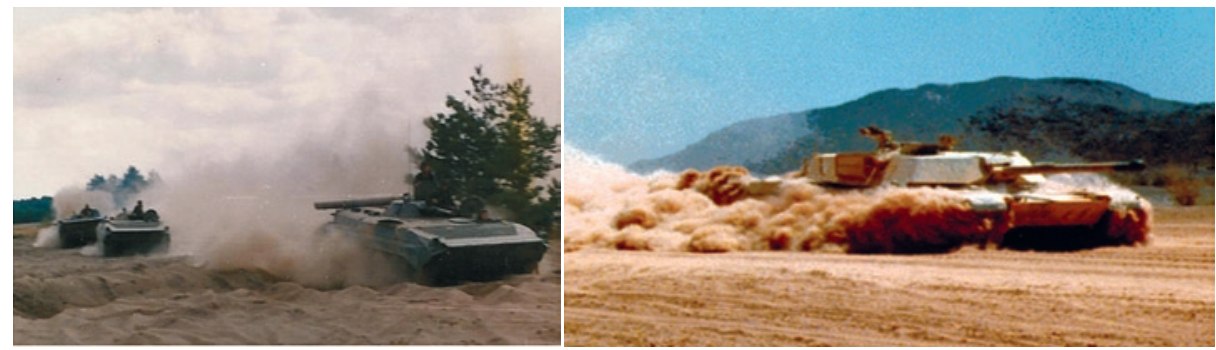

the daily maintenance (Fig. 4a). In modern air filter solutions, dust is extracted from the dust collector using automatic methods:

- by opening rubber drain cones after each engine stop (Fig. 4b),

- in continuous mode by generating an air stream flow $Q_{S}$ - extraction stream (ejection effect) (Fig. 4c).

Fig. 3. Visibility limited due to the operation of: a) infantry fighting vehicle, b) tanks [18] 

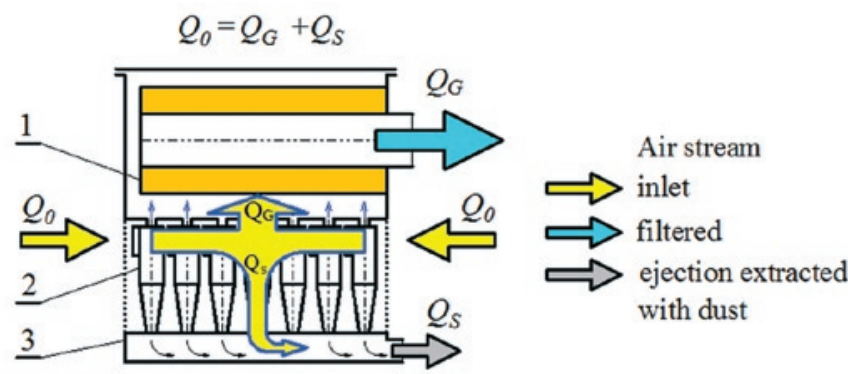

Fig. 5. Distribution of the inlet air stream in the filter with ejection dust extraction from the dust collector: 1 - panel filter, 2 - multi-cyclone, 3 -dust collector

The dust is extracted by an air stream $Q_{S}$, a part of an inlet air stream (with dust) $Q_{0}$ to the multi-cyclone (Fig. 5):

$$
Q_{0}=Q_{G}+Q_{S},
$$

where: $Q_{G}$ - filter outlet air stream (clean) - engine inlet air.

Special fans and blowers are commonly used to generate the extraction stream. A major drawback of the solution is that it requires a drive, i.e. electric motor or mechanical gear coupled with the engine crankshaft. The fan performance depends directly on the engine speed, and as a result on its operating range. The fan location within the engine compartment is also pre-determined and is not necessarily optimal in relation to the filter position. Continuous fan operation also entails high requirements regarding the motor durability. The electric drive is a significant load on the system generating electrical energy for the vehicle subsystems. A fan with electric drive is used to extract dust from the air filter dust collector in Leopard 2 tanks.

To generate the extraction stream in many air filters, ejectors utilizing the energy of a compressed air stream [4] or an exhaust gas from the vehicle's exhaust system $[2,11]$ are used.

The extraction stream $Q_{S}$ flowing through the dust collector chamber captures the dust particles and is discharged via conduits outside the vehicle.

The purpose of the ejector is to force and intensify the extraction stream flow between two spaces, usually two open thermodynamic

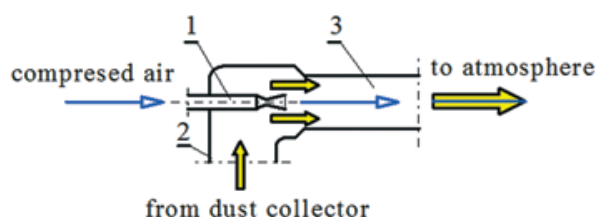

c)

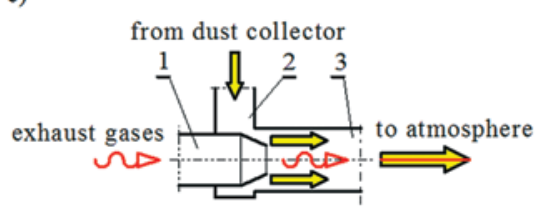

Fig. 6. Ejector configuration in the extraction system for forced ejection stream: a) compressed air, $b$ and c) exhaust gases: 1 - active stream inlet channel, 2 - passive stream inlet channel, 3 - mixing chamber [10] systems. The characteristic feature of the ejector are two streams, between which there is a transfer of momentum. The active stream has a higher momentum vector value, and its sense is strictly determined. The vector sense of the second stream (passive) is usually identical. Due to the different methods of stream delivery: active and passive, different ejector configurations are available (Fig. 6).

From the configurations shown in Fig. 6, the more practical and more commonly used in the exhaust system is the configuration shown in Fig. 6b. It is significantly easier to manufacture and has a lower weight, which in case of a vibrating exhaust system is of crucial importance. The ejector configuration is used in the ejection dust extraction from the dust collector of the T-72 and PT-91 tank air filter and special vehicles using the same suspension.

The ejector has a simple design, small number of components and no movable parts. It requires very little maintenance apart from periodical visual inspection of the technical condition and integrity of the conduit connecting the ejector with the dust collector of the inertial filter. However, the ejector requires additional energy to provide dust extraction capabilities.

The measure of an intensity of dust extraction from the multicyclone (cyclone) dust collector is the extraction rate $m_{0}$ defined as a quotient of air stream flow rate $Q_{S}$ in the extraction system and the multi-cyclone (cyclone) outlet stream flow rate, and if the multi-cyclone is used as the first stage of air filtration in the air filter - to the

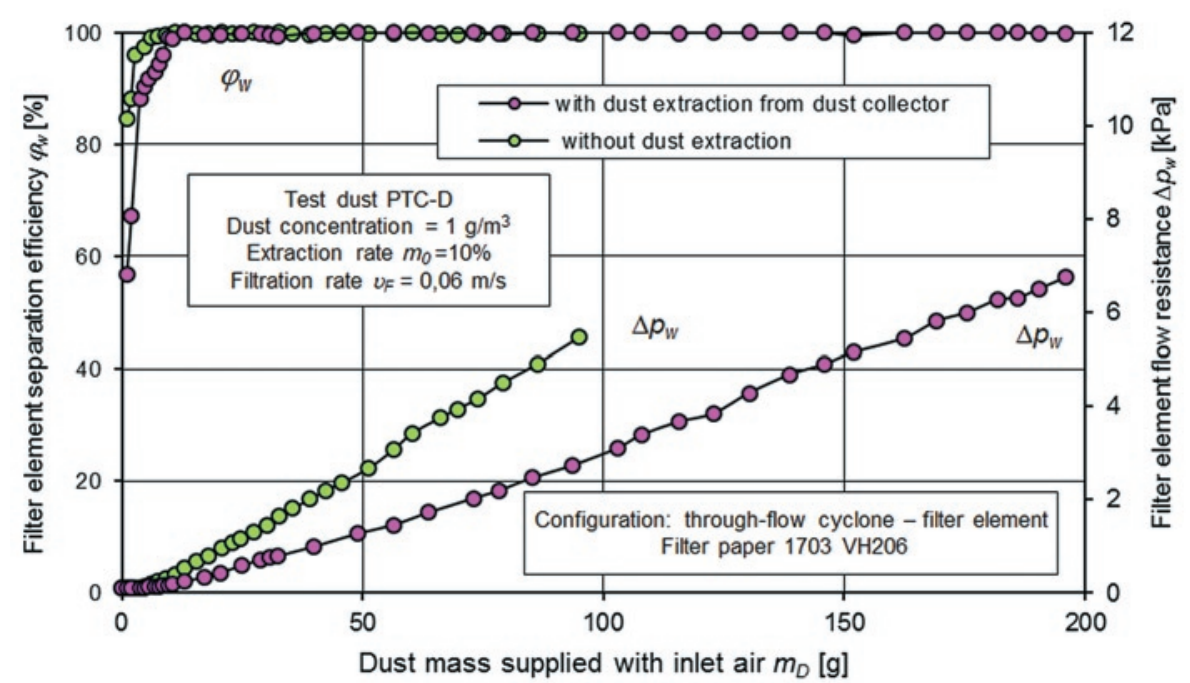

Fig. 7. Characteristics of the paper filter element downstream of the through-flow cyclone with and without dust extraction from the cyclone dust collector [12] b)

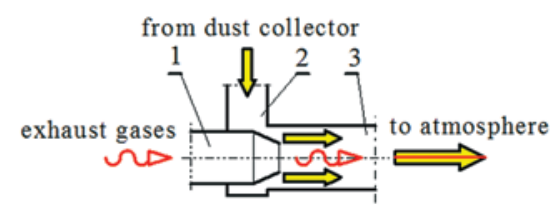

air filter outlet stream flow rate $Q_{G}$ (engine inlet air) $[10,19,23,31]$ :

$$
m_{0}=\frac{Q_{S}}{Q_{G}} 100 \%
$$

Removing (by extraction) the dust separated by the cyclones from the multi-cyclone dust collector results in a significant increase in separation efficiency, and thus extends the air filter life by a limited determined permissible flow resistance $\Delta p_{\text {fdop }}$. The characteristics can be verified by the flow resistance $\Delta p_{w}=f\left(m_{D}\right)$ and separation efficiency $\varphi_{w}=f\left(m_{D}\right)$ characteristics of a paper panel filter as a function of dust mass $m_{D}$ 


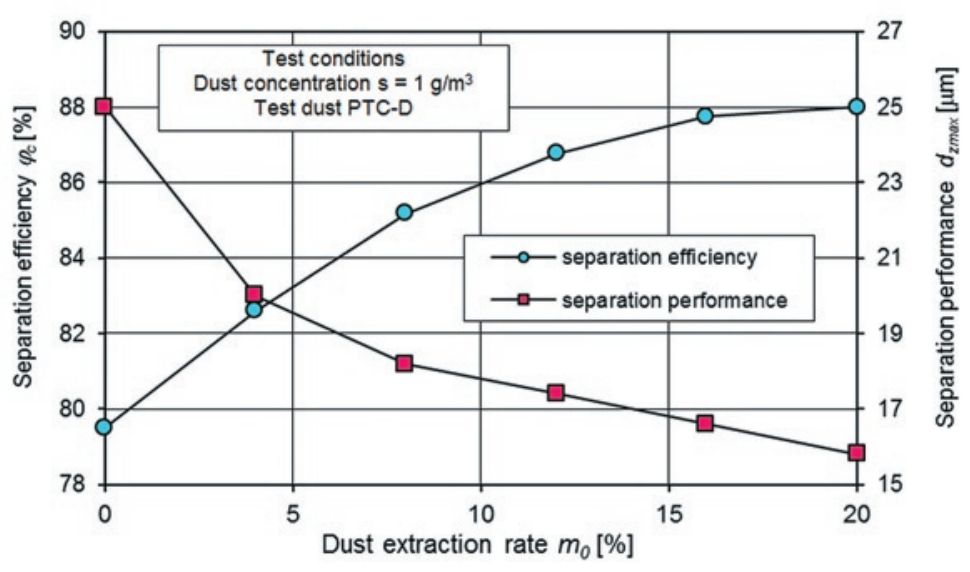

Fig. 8. Effects of the extraction rate $m_{0}$ on cyclone separation efficiency and flow resistance [14]

supplied with inlet air in serial 'cyclone - filter element' configuration (Fig. 7).

The studies on the effects of dust extraction on separation efficiency in cyclones, however scarce show that the increase in extraction rate $m_{0}$ results in a significant increase in cyclone efficiency $\varphi_{c}$, up to a certain point (Fig. 8 and 9). For through-flow cyclone (Fig. 8) the limit value is $m_{0 g}=10 \div 15 \%$ [14].

An increase in the extraction rate $m_{0}$ results in an increase in cyclone flow resistance due to the increase in stream volume $Q_{0}$ and air flow rate.

There is a specific range of optimal extraction rate, which if exceeded may affect cyclone performance and increase energy losses. In the existing cyclone and multi-cyclone designs, the extraction rate $m_{0}$ is usually within $m_{0}=8 \div 15 \%$, although it may sometimes reach $m_{0}=20 \%[10,19,23,31]$.

\section{Test purpose, methods and conditions}

The study aimed to determine the causes of the decrease in multicyclone separation efficiency depending on the mass of dust supplied to the two-stage filter and the effects of those changes on the perfor-

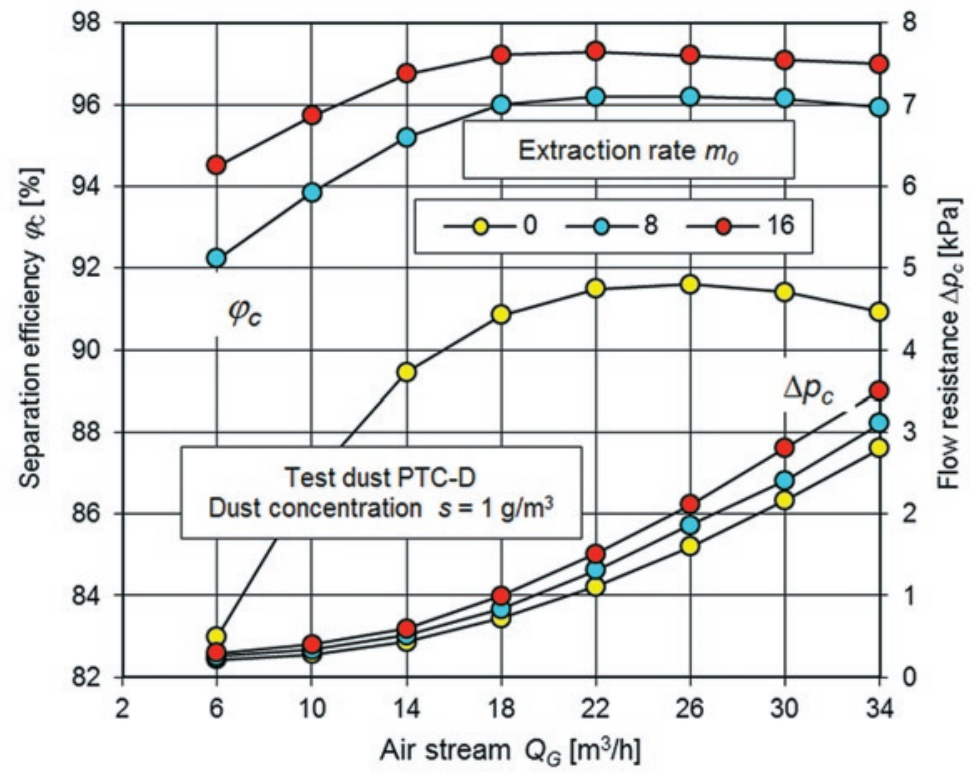

Fig. 9. Effects of the extraction rate $m_{0}$ on characteristics: separation efficiency $\varphi_{c}=f\left(Q_{G}\right)$ and flow resistance $\Delta p_{c}=f\left(Q_{G}\right)$ of a return-flow cyclone with tangential inlet $D-40[12]$ mance of a non-woven fabric filter used in the two-stage filtration system downstream of the multi-cyclone.

The purpose of the study was to determine the performance characteristics of a non-woven fabric filter in a two-stage filtration system and a multi-cyclone at a pre-determined air stream flow rate $Q_{G}$ and ejection dust extraction rate from the multicyclone dust collector. The characteristics were determined for three different ejection dust extraction rates $m_{0}=5 \%, m_{0}=10 \%$, $m_{0}=20 \%$ and without extraction, as well as without extraction with periodical removal of the dust from the dust collector. The ejection dust extraction rates $m_{0}$ used are based on the range of the extraction rates recorded in the existing and operating multicyclone designs.

The following characteristics were determined:

- filter element separation efficiency $\varphi_{w}=f\left(m_{D}\right)$,

- filter element flow resistance $\Delta p_{w}=f\left(m_{D}\right)$,

- multi-cyclone separation efficiency $\varphi_{M}=f\left(m_{D}\right)$.

Table 1. AC-301 non-woven fabric filter parameters by Korea Filtration Technologies $\mathrm{Co}$.

\begin{tabular}{||c|c|c||}
\hline Parametr & Unit & Value \\
\hline Weight per unit area & $\left(\mathrm{g} / \mathrm{m}^{2}\right)$ & $210 \pm 10 \%$ \\
\hline Thickness & $(\mathrm{mm})$ & $2.34 \div 2.86$ \\
\hline Air permeability & $\left(\mathrm{dm}^{3} / \mathrm{m}^{2} / \mathrm{s}\right)$ & $800 \div 1100$ at $120 \mathrm{~Pa}$ \\
\hline Tensile strength & $(\mathrm{N} / 50 \mathrm{~mm})$ & $>98$ \\
\hline Bending strength & $(\mathrm{N} / 30 \mathrm{~mm})$ & $1.47 \div 2.94$ \\
\hline
\end{tabular}

a)

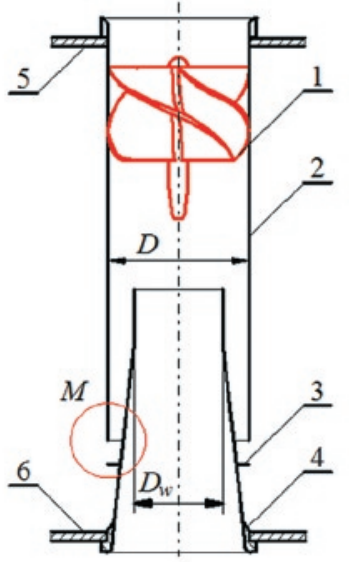

b)

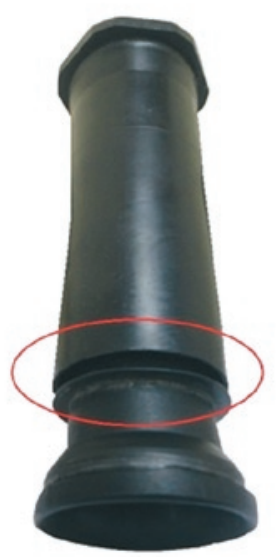

Fig. 10. Through-flow cyclone of the tested multi-cyclone: a) functional diagram, b) general view: 1 -swirl vanes, 2-body, 3-abutment, 4 - outlet tube, 5 - multi-cyclone top plate, 6 - multi-cyclone bottom plate, $D$ - cyclone body internal diameter, $D_{w}-$ outlet tube internal diameter, $M$-extracted dust outlet gap

The tests covered a filter element made of two-layer nonwoven fabric AC-301 (Table 1) with a filtration surface area $F_{w}=2 \mathrm{~m}^{2}$ and a multi-cyclone including through-flow cyclones (Fig. 10) arranged parallel in relation to each other in three columns, six cyclones per column - Fig. 11.

The main stream value was $Q_{G}=600 \mathrm{~m}^{3} / \mathrm{h}$. The dust was extracted from the dust collector of the multi-cyclone using ejection extraction with the air stream $Q_{S}$.

The extraction stream flow rate $Q_{S}$ was determined from the following relationship for the extraction rates used $m_{0}=5 \%$, $m_{0}=10 \%, m_{0}=20 \%$ : 


$$
Q_{S}=Q_{G} \cdot m_{0}
$$

The tests were performed at a constant air stream flow through the filter $Q_{G}=600 \mathrm{~m}^{3} / \mathrm{h}$ (separation rate $v_{F d o p}=0.08 \mathrm{~m} / \mathrm{s}$ ) and extraction stream flow rates $Q_{s}=30 \mathrm{~m}^{3} / \mathrm{h}, Q_{s}=60$ $\mathrm{m}^{3} / \mathrm{h}, Q_{s}=120 \mathrm{~m}^{3} / \mathrm{h}$, at dust concentration in the air at multi-cyclone inlet $s=1 \mathrm{~g} / \mathrm{m}^{3}$, using PTC-D type test dust, locally available equivalent to AC-Fine test dust, with size distribution and chemical composition as specified in [13].

The separation efficiency $\varphi_{w}$ of tested nonwoven textile filter and multi-cyclone was determined using a mass method in subsequent $j$ measuring cycles, with the duration (uniform test dust dispensing and distribution time) of $t_{\text {Ipom }}=3 \mathrm{~min}$ in the initial separation period and $t_{2 \text { pom }}=15 \mathrm{~min}-$ in the subsequent period.

The following were determined after each $j$-th cycle:

- filter element separation efficiency $\varphi_{w}$ from the following equation:

$$
\varphi_{w j}=\frac{m_{w j}}{m_{D w j}} \cdot 100 \%,
$$

where: $m_{w j}-$ dust mass retained by filter element, $m_{D w j}-$ dust mass supplied to the filter element (downstream of the multi-cyclone) during the measurement cycle.

- multi-cyclone separation efficiency $\varphi_{M}$ from the following equation:

$$
\varphi_{w j}=\frac{m_{M j}}{m_{D j}} \cdot 100 \%,
$$

where: $m_{M j}$ - dust mass retained by multi-cyclone, $m_{D j}$ - dust mass supplied to the multi-cyclone (filter) in the measurement cycle.

- filter element flow resistance from the following equation:

$$
\Delta p_{w j}=\frac{\Delta h_{w j}}{1000}\left(\rho_{m}-\rho_{H}\right) g[\mathrm{kPa}]
$$

where: $\Delta h_{w}$ - static pressure drop as read (in $\mathrm{mm} \mathrm{H}_{2} \mathrm{O}$ ) from the water manometer (U-tube), $\rho_{m}$ - manometer liquid density $\left(\mathrm{H}_{2} \mathrm{O}\right)$ at measurement temperature $t_{H}, \rho_{H}-$ atmospheric air density in $\mathrm{kg} / \mathrm{m}^{3}, g$ - local gravitational acceleration.

- dust concentrations in the air from the following equation:

$$
s_{j}=\frac{m_{D j} \cdot 60}{\left(Q_{G}+Q_{s}\right) \cdot \tau_{j p o m}}\left[\mathrm{~g} / \mathrm{m}^{3}\right],
$$

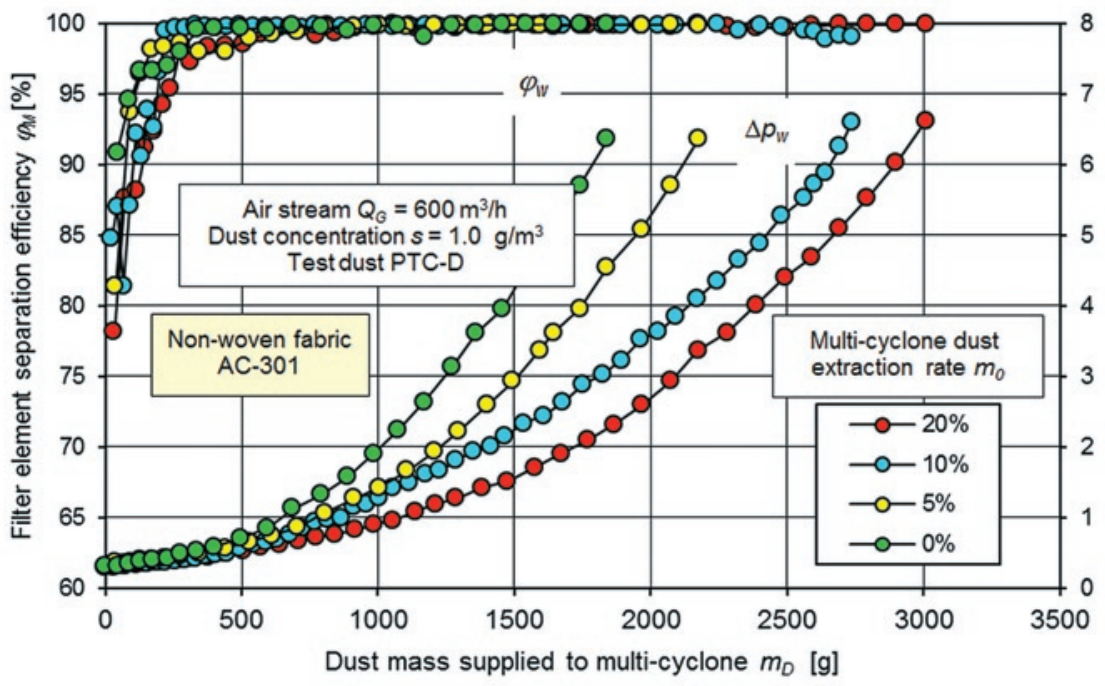

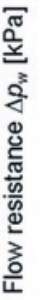

Fig. 12. Separation efficiency and flow resistance of the filter element (AC-301 non-woven fabric) used as a second filtration stage downstream of the multi-cyclone for different rates of $m_{0}$ ejection dust extraction from the dust collector 


\section{Test result analysis}

Fig. 12 shows the separation efficiency $\varphi_{w}$ and flow resistance $\Delta p_{w}$ characteristics for non-woven fabric filter AC-301 in two-stage filtration configuration (downstream of the multi-cyclone) as a function of dust mass $m_{D}$ supplied with inlet air to the filter. The filter element life can be divided into two periods due to the achieved separation efficiency. First (initial) period is characterized by a low separation efficiency, which systematically and rapidly increases with the volume of dust supplied to the filter. The initial period lasts from the beginning of the separation process until the non-woven fabric reaches the separation efficiency of $99.5 \%$ [8]. Main filtration period is characterized by a high (over $99.5 \%$ ) and slowly but gradually increasing separation efficiency. Following the initial measurement cycles, AC-301 non-woven fabric filter efficiency was $\varphi_{w}=78.8 \div 88.3 \%$ (Fig. 12). The initial period (separation efficiency $\varphi_{w}=99.5 \%$ ) for the tested non-woven fabric ends after approx. $450 \mathrm{~g}$ of dust is supplied to the filter.

The flow resistance $\Delta p_{w}$ of the filter element increases with the increase in the dust mass supplied to the filter, and the increase rate is higher the lower the dust extraction rate $m_{0}$. Determined flow resistance $\Delta p_{w}=6 \mathrm{kPa}$ is achieved by the filter element, after a specific dust mass is supplied to the filter. The operation of the multi-cyclone at the extraction rate of $m_{0}=20 \%$ means, that the filter element achieves the flow resistance of $\Delta p_{w}=6 \mathrm{kPa}$ after supplying $m_{D}=2.9 \mathrm{~kg}$ of dust to the system. For the extraction rate $m_{0}=10 \%$ the value is $m_{D}$ $=2.7 \mathrm{~kg}$, whereas for $m_{0}=5 \%$ it is $m_{D}=2.1 \mathrm{~kg}$. The operation of the multi cyclone without dust extraction from the dust collector means that the filter element achieves a flow resistance of $\Delta p_{w}=6 \mathrm{kPa}$ after supplying to the system $m_{D}=1.8 \mathrm{~kg}$ of dust, which corresponds to less than $40 \%$ compared to the multi-cyclone operation with dust extraction $m_{0}=20 \%$. Time the air filtration system requires to reach a permissible air filter flow resistance $\Delta p_{\text {fdop }}$ is significantly shorter compared to the configuration with the dust extraction from the dust collector.

The effect is due to the reduced separation efficiency of the multi-cyclone at a reduced rate of dust extraction from the dust collector and reduced multi-cyclone separation efficiency in time - increased mass of dust supplied to the system (Fig. 13).
With the increase in dust mass supplied to the filter with inlet air, the separation efficiency of multi-cyclone gradually decreases, however the lower the dust extraction rate $m_{0}$ the higher the efficiency reduction rate. The moment the multi-cyclone begins operation at the dust extraction rate $m_{0}=20 \%$, its efficiency is $\varphi_{M}=86.25 \%$, and after supplying over $3 \mathrm{~kg}$ of dust, the efficiency is reduced to $\varphi_{M}=61.72 \%$. For multi-cyclone operation at dust extraction rate of $m_{0}=5 \%$, the respective values are: initial $\varphi_{M}=76.2 \%$ and after delivering $m_{D}=$ $2.17 \mathrm{~kg}$ of dust $-\varphi_{M}=24.2 \%$. The multi-cyclone separation efficiency in this case is reduced threefold. The reduction in multi-cyclone separation efficiency means that the larger dust mass is delivered to the filter element, resulting in rapid filling of the filter medium pores, and thus progressively increasing the flow rate $v$ between the fibres. It results in a significant increase in the flow resistance (Fig. 12) as a function of $\Delta p=f\left(v^{2}\right)$.

If the dust collector is common for many cyclones, and the dust is extracted via one or two ports, as in tested configuration, the following can be observed $[8,9,16]$ :

- extraction stream values differ for individual cyclones,

- whirling streams from individual cyclones entering the common dust collector interact with each other,

- backflow to the cyclones at the multi-cyclone periphery may occur.

Those effects may not only results in a multi-cyclone efficiency lower than resulting from the extraction rate for individual cyclones, but also in the reduction of multi-cyclone separation efficiency with the increase in dust mass delivered with air to the filter. It will thus result in:

1) Permanent deposition of dust on internal surfaces of the inlet components of the cyclone forming a gap, through which the extracted dust is discharged - Fig. 14. The mass of dust

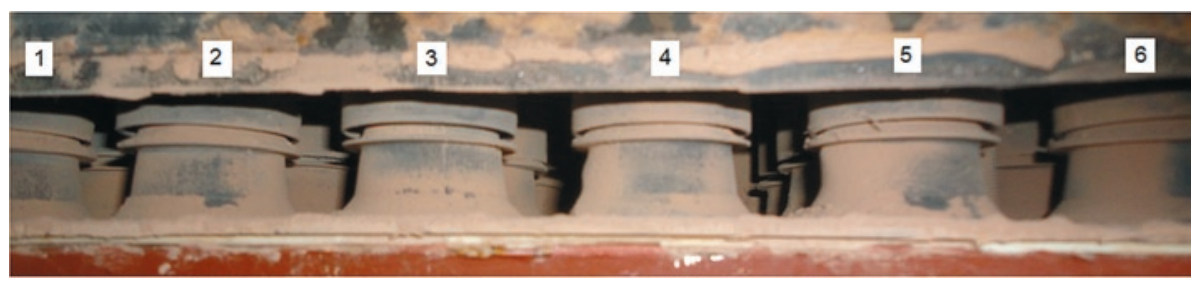

Fig. 14. Cyclone outlet gaps after supplying $500 \mathrm{~g}$ of dust at dust extraction rate of $m_{0}=5 \%-v i e w$ from the dust extraction manifold: 1, 2, 3, .., 6 -consecutive cyclone number in the column

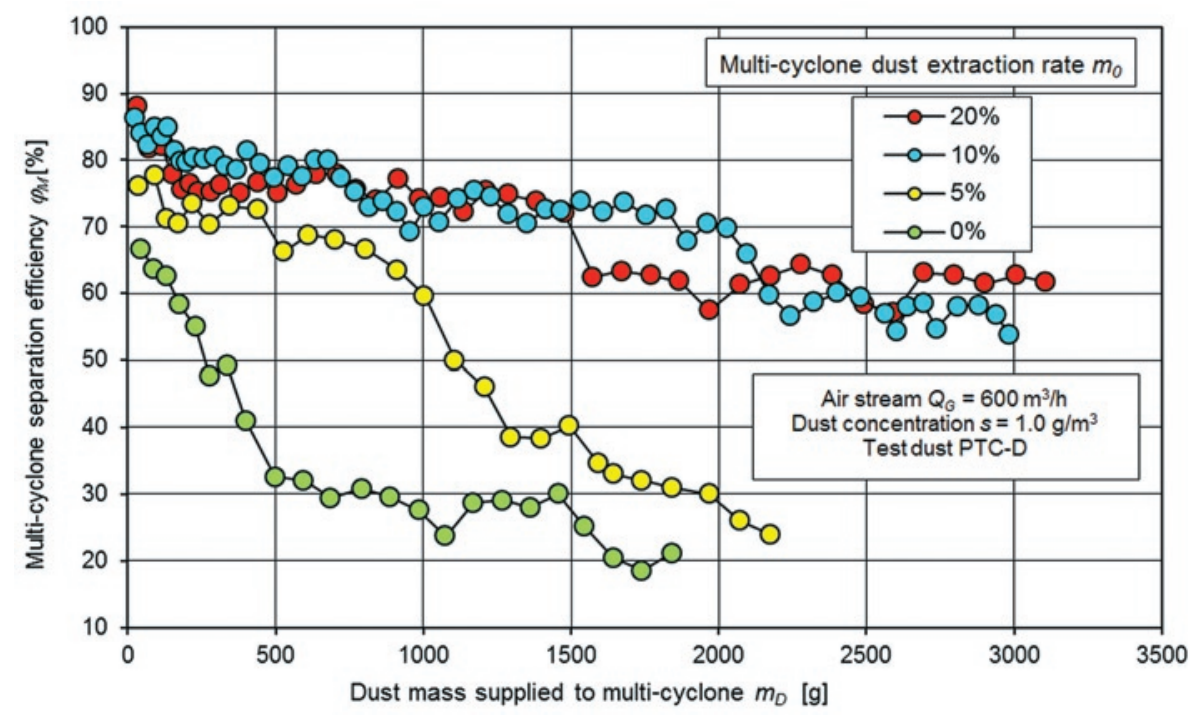

Fig. 13. Separation efficiency of the multi-cyclone at different rates $m_{0}$ of ejection extraction from the dust collector deposits in the gap increases with time, and as a result affects the extraction stream flow from the cyclone and thus may render it completely ineffective - Fig. 15.

2) Permanent deposition of dust in the corners and at the rim of the dust collector housing (Fig. 15), where the extraction is less effective compared to the cyclones closer to the extraction duct. The dust accumulated and deposited on the bottom of the dust collector affects the flow at the cyclone outlet of both the extracted dust and the clean air. As a result, the air flow through the cyclone is gradually reduced, and thus reduces its separation efficiency. The mass of dust deposited on the bottom of the dust collector and the rim increases with time, and as a result may clog the cyclone outlets and thus render it completely ineffective (Fig. 15).

The rate with which those effects, reducing the multi-cyclone separation efficiency with the 


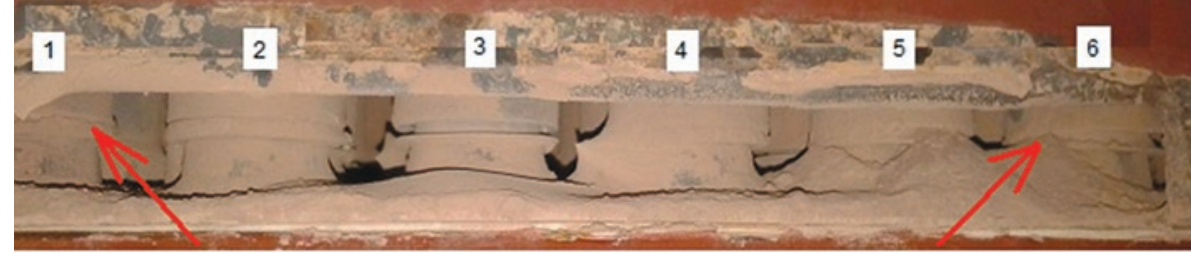

Fig. 15. Cyclone outlet gaps after supplying $2150 \mathrm{~g}$ of dust at dust extraction rate of $m_{0}=5 \%-v i e w$ from the dust extraction manifold: 1, 2, 3, .., 6-consecutive number of the cyclone in the column (arrow indicates the cyclones with gaps clogged with dust)

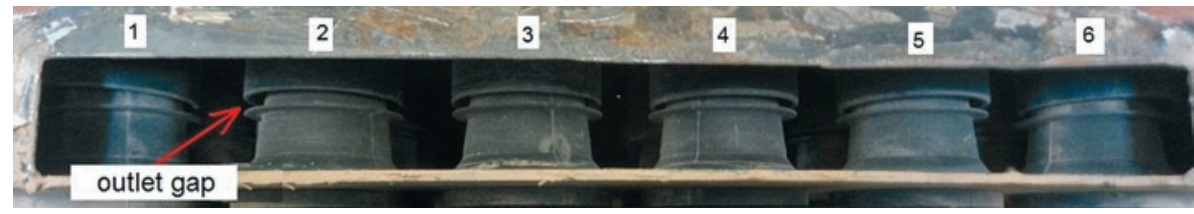

Fig. 16. Cyclone outlet gaps after maintenance - view from the dust extraction manifold:1, 2, 3, ... , 6 consecutive cyclone number in the column

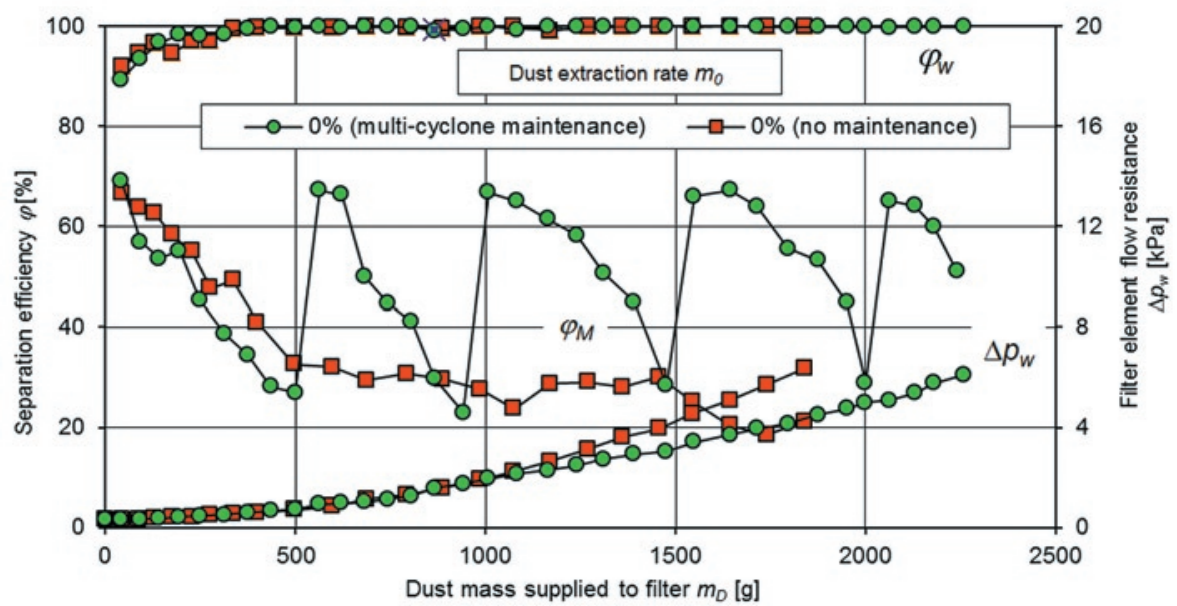

Fig. 17. Effects of periodical dust extraction from the dust collector on separation efficiency and flow resistance of the filter element (non-woven fabric AC-301) and multi-cyclone separation efficiency without ejection dust extraction from the dust collector.

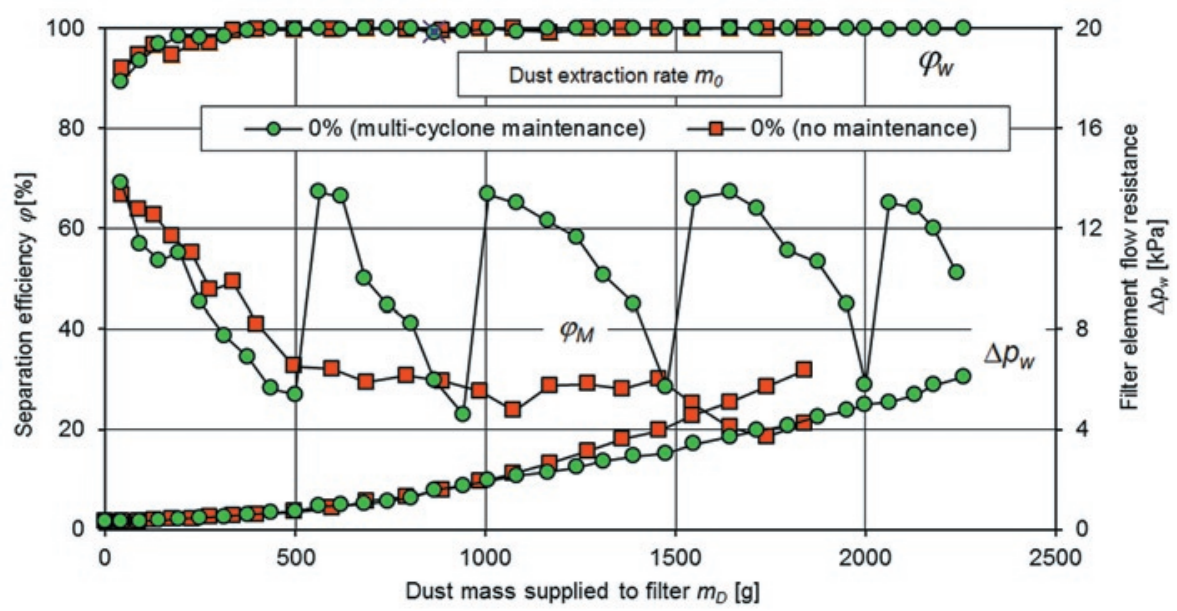

Fig. 18. Effects of dust mass supplied on the separation efficiency of multi-cyclone, filter element (AC-301 non-woven fabric) and complete filter at the ejection extraction rate of $m_{0}=10 \%$

increase in mass of dust supplied to the filter, occur is higher the lower the dust extraction rate from the dust collector.

A decrease in multi-cyclone separation efficiency during operation may be prevented by periodical cleaning of the dust collector. Fig. 17 shows changes in the multi-cyclone separation efficiency with the mass of dust supplied to the filter without extraction and with periodical dust extraction (every $500 \mathrm{~g}$ of supplied dust) from the dust collector. At the beginning, the multicyclone separation efficiency was $\varphi_{M}=69.1 \%$, and after supplying $500 \mathrm{~g}$ of dust, the efficiency was reduced to $\varphi_{M}=26.9 \%$, which is similar to the value achieved by the multi-cyclone without maintenance. After the maintenance (Fig. 16) involving dust removal with compressed air, the multi-cyclone separation efficiency has increased to $\varphi_{M}=66.8 \%$, which is similar to the initial value, and was further reduced in subsequent operation. The multi-cyclone maintenance cycle was repeated three times with a similar result - Fig. 17.

Separation efficiency of a complete twostage air filter is determined both by the multi-cyclone and the filter element. In the initial stage, when the filter element achieves low efficiency within $\varphi_{w}=81.4 \div 96.6 \%$, its efficiency is determined by the multi-cyclone, providing maximum separation efficiency of $\varphi_{M}=$ $86.3 \div 81.4 \%$ (Fig. 18). The reduction in multicyclone separation efficiency with the mass of dust supplied with the inlet air (vehicle mileage) does not affect separation efficiency of the complete filter.

For multi-stage filters, where the filtration stages are arranged in series, the separation efficiency is usually determined using the following equation [20]:

$$
\varphi_{f}=1-\prod_{i=1}^{n}\left(1-\varphi_{f i}\right),
$$

where: $n$ - number of filtration stages, $\varphi_{f i}-i$-th stage separation efficiency.

For the tested two-stage filter, where the first filtration stage (multi-cyclone) is characterized by the initial separation efficiency of $\varphi_{M 1}=86.25 \%$, and the second stage (filter element) $\varphi_{w l}=84.78 \%$ (Fig. 18), the separation efficiency is:

$$
\begin{gathered}
\varphi_{f 1}=1-\prod_{i=1}^{n}\left(1-\varphi_{i}\right) \\
\varphi_{f 1}=1-\left(1-\varphi_{M 1}\right) \cdot\left(1-\varphi_{w 1}\right) \\
\varphi_{f 1}=1-(1-0.8625) \cdot(1-0.8478) \\
\varphi_{f 1}=97.91 \% .
\end{gathered}
$$

Experimental initial separation efficiency of the filter is $\varphi_{f E l}=97.908 \%$.

After supplying $m_{D}=2028.6 \mathrm{~g}$ of dust (measuring cycle no. 44 Fig. 18), experimental separation efficiency of the two-stage filter is $\varphi_{f E 44}=99.97 \%$, whereas the separation efficiency determined using a relationship $\left(\varphi_{M 44}=67.73 \%, \varphi_{w 44}=99.9 \%\right)$ is similar 
$\varphi_{f 44}=99.967 \%$. Very high agreement of the experimental and calculation results of the separation efficiency of the two-stage filter indicates that the selected test method is accurate.

\section{Summary}

Two-stage (multi-cyclone - porous panel filter) filtration systems with ejection dust extraction from the dust collector are used in the filtration systems at the air inlets of the motor vehicles operating in high dust concentration conditions ( $\mathrm{s}=1 \mathrm{~g} / \mathrm{m}^{2}$ and more).

The studies and analyses show, that the ejection dust extraction from the dust collector of the multi-cyclone used in the two-stage filter system performs its task, however it is not perfect, due to the decreasing separation efficiency of the multi-cyclone and more intensive increase in flow resistance of the filter element.

With the increase in dust mass supplied to the filter with inlet air, the separation efficiency of multi-cyclone gradually decreases, however the lower the dust extraction rate $m_{0}$ the higher the efficiency reduction rate (Fig. 13). It is due to the specific design of the multicyclone and imperfections of the dust extraction system. If the dust collector is common for many cyclones, and the dust is extracted via one or two ports, the extraction streams for individual cyclones vary and the backflow in the cyclones located at the perimeter of the multicyclone may occur.

It may result in a permanent deposition of dust in the corners and at the rim of the dust collector housing, where the extraction is less effective compared to the cyclones closer to the extraction duct. The dust accumulated and deposited on the bottom of the dust collector affects the flow at the cyclone outlet of both the extracted dust and the clean air, which, in effect, may clog the cyclone outlets and thus render them completely ineffective. The rate of these effects is higher at lower extraction rate or multi-cyclone operation without the dust extraction from the dust collector.

In the operating conditions, it can be compensated by periodical, systematic cleaning of the dust collector and cyclone outlet slots. The multi-cyclone separation efficiency restored to its initial value has been shown (Fig. 17), however it is a difficult task, since it requires the filter to be removed from the vehicle.

The air filters in special vehicles are characterized by large dimensions and weight, and usually does not allow disassembly of the dust collector.

The settling of the dust both in the corners and on the edges of the dust collector housing and in the slots of the cyclones at the multicyclone circumference may be prevented with a suitable design of the inner space of the dust collector chamber. One of the methods is to divide the dust collector chamber of the multi-cyclone into individual segments and suction ducts, with assigned corresponding groups of individual cyclones. The design may provide uniform flow rates for all cyclones and prevent permanent settling of the dust in the corners and on the edges of the dust collector housing.

A segmented dust collector is also easier to design, since the basic tests are limited to individual segments, and thus easier and more cost effective.

The intensity of the increase in flow resistance $\Delta p_{w}$ of the filter element used as a second filtration stage (downstream of the multicyclone) is higher, the lower the separation efficiency of the multicyclone. As a result, more dust is supplied to the filter element in a unit of time. Thus, in normal operation at constant permissible flow resistance $\Delta p_{f d o p}$, the mean time between maintenance is reduced and the operational costs are increased.

\section{References}

1. Azadi M, Azadi M. An analytical study of the effect of inlet velocity on the cyclone performance using mathematical models. Powder Technology 2012; 217: 121-127, http://dx.doi.org/10.1016/j.powtec.2011.10.017.

2. Baczewski K, Hebda M. Filtracja płynów eksploatacyjnych. Radom: MCNEMT, 1991/92.

3. Cernecky J, Plandorova K. The effect of the introduction of an exit tube on the separation efficiency in a cyclone. Brazilian Journal of Chemical Engineering 2013; 30 (3): 627-641, http://dx.doi.org/10.1590/S0104-66322013000300020.

4. Cenrtisep Air Cleaner.: Materiały informacyjne firmy PALL Corporation, USA 2004.

5. Chłopek Z. Testing of hazards to the environment caused by particulate matter during use of vehicles. Eksploatacja i Niezawodnosc Maintenance and Reliability 2012; 2: 160-170.

6. Chłopek Z, Jakubowski A. A study of the particulate matter emission from the braking systems of motor vehicles. Eksploatacja i Niezawodnosc - Maintenance and Reliability 2009; 4: 45-52.

7. Chu K W, Wang B, Xu D L, Chen Y X, Yu A B. CFD-DEM simulation of the gas-solid flow in a cyclone separator. Chemical Engineering Science 2011; 66: 834-847, http://dx.doi.org/10.1016/j.ces.2010.11.026.

8. Chuah L A, Gimbun J, Choong T S Y, Fakhru'l-Razi A. A CFD analysis on the effect of vortex finder and cylindrical length on cyclone hydrodynamics and centrifugal forces. Journal - The Institution of Engineers, Malaysia 2009; 71 (2): 51-58.

9. Durst M, Klein G, Moser N. Filtration in Fahrzeugen. Materiały informacyjne firmy Mann+Hummel GMBH. Ludwigsburg, Niemcy 2005.

10. Dziubak T. The assessment of the possibilities of improvement of the extraction evenness, in multicyclone dedusters fitted in special vehicles. Combustion Engines 2012; 4 (151): 34-42.

11. Dziubak T.: A study on the improvement of uniformity of dust extraction from multicyclone dust collectors. Combustion Engines 2011; 4(147): 69-78.

12. Dziubak T.: The research of air filtration process on paper partition in the Cyclone-porous partition" system. Journal of KONES Powertrain and Transport 2007; 2(14): 115-124.

13. Dziubak T., Szwedkowicz S.: Operating properties of non-woven fabric panel filters for internal combustion engine inlet air in single and two-stage filtration systems. Eksploatacja i Niezawodnosc - Maintenance and Reliability 2015; 17(4): 519-527, http://dx.doi.org/10.17531/ ein.2015.4.6.

14. Dziubak T, Szwedkowicz S. Experimental research on filtering fibers in a cyclone-porous barrier system. Combustion Engines 2014; 3(158): 45-55.

15. Elsayed K. Optimization of the cyclone separator geometry for minimum pressure drop using Co-Kriging. Powder Technology 2015; 269: 409-424, http://dx.doi.org/10.1016/j.powtec.2014.09.038.

16. Fitch J. Clean Oil Reduces Engine Fuel Consumption. Practicing Oil Analysis Magazine 2002; 11-12.

17. Gawali S S, Bhambere M B. Computational fluid dynamics approach for prediction of cyclone separator pressure drop. International Journal of Mechanical Engineering and Robotics Research 2015; 4 (1): 374-377. 
18. Grafe T, Gogins M, Barris M, Schaefer J, Canepa R. Nanofibers in Filtration Applications in Transportation. Filtration International Conference and Exposition, Chicago - Illinois, December 3-5, 2001.

19. Greenfield R. R. The Use of Cyclones for Control of Solids Emission from Fluidised Bed Boilers. Filtration \& Separation 1986; 22 (1): $38-39$.

20. Jaroszczyk T. Air Filtration in Heavy-Duty Motor Vehicle Applications. Proc. Dust Symposium III Vicksburg MS, 15-17 September 1987.

21. Jiao J, Zheng Y, Sun G, Wang J. Study of the separation efficiency and the flow field of a dynamic cyclone. Separation and Purification Technology 2006; 49: 157-166, http://dx.doi.org/10.1016/j.seppur.2005.09.011.

22. Karagoz I, Avci A, Surmen A, Sendogan O. Design and performance valuation of a new cyclone separator. Journal of Aerosol Science 2013; 59: 57-64, http://dx.doi.org/10.1016/j.jaerosci.2013.01.010.

23. Kim H T, Zhu Y, Hinds W C, Lee KW. Experimental study of small virtual cyclones as particle concentrators. Journal of Aerosol Science 2002; 5(33): 721-733, http://dx.doi.org/10.1016/S0021-8502(01)00212-9.

24. Koszałka G, Suchecki A. Changes in performance and wear of small diesel engine during durability test. Combustion Engines 2015; 3(162): $34-40$.

25. Koszałka G. Model of operational changes in the combustion chamber tightness of a diesel engine. Eksploatacja i Niezawodnosc Maintenance and Reliability 2014; 1: 133-139.

26. Ma L, Ingham D. B, Wen X. Numerical modelling of the fluid and particle penetration through small sampling cyclones. Journal of Aerosol Science 2000; 9(31): 1097-1119, http://dx.doi.org/10.1016/S0021-8502(00)00016-1.

27. Pui D Y H, Chen S Ch, Zuo Z. PM2.5 in China: Measurements, sources, visibility and health effects, and mitigation, Particuology 2014; 13: 1-26, http://dx.doi.org/10.1016/j.partic.2013.11.001.

28. Qian F, Zhang J, Zhang M. Effects of the prolonged vertical tube on the separation performance of a cyclone. Journal of Hazardous Materials 2006; 136: 822-829, http://dx.doi.org/10.1016/j.jhazmat.2006.01.028.

29. Reddy G C, Kuppuraj U. Numerical study of flue gas flow in a multi cyclone separator. Int. Journal of Engineering Research and Applications 2015; 5(1): 48-53.

30. Rybak P. Operating loads of impulse nature acting on the special equipment of the combat vehicles. Eksploatacja i Niezawodnosc Maintenance and Reliability 2014; 3: 347-353.

31. Sage P W, Wright M A. The Use of Bleeds to Enhance Cyclone Performance. Filtration \& Separation 1986; 1(23): 32-36.

32. Wang B, Xu D L, Chu K W, Yu A B. Numerical study of gas-solid flow in a cyclone separator. Applied Mathematical Modelling 2006; 30: 1326-1342, http://dx.doi.org/10.1016/j.apm.2006.03.011.

\section{Tadeusz DZIUBAK}

Military University of Technology

Faculty of Mechanical Engineering

ul. Gen. Sylwestra Kaliskiego 2, 00-908 Warsaw, Poland

E-mail: tadeusz.dziubak@wat.edu.pl 